\title{
SIRENOMELIA: A CASE REPORT
}

\author{
S. K. Wankhede1, S. Shrivastava ${ }^{2}$
}

1 Professor, Department of Anatomy, Amaltas Institute of Medical Sciences, Dewas.

2Professor, Department of Anatomy, Amaltas Institute of Medical Sciences, Dewas.

\section{ABSTRACT}

The incidence of Sirenomelia is thought to be about 1 in 65,000 live births (Oxford Medical database, Dysmorphology). In Sirenomelia, lower limbs are fused together. Common associated malformations include absent genitalia, imperforate anus, lumbosacral vertebral pelvic abnormalities and renal agenesis. Sirenomelia with craniorachischisis totalis (CT) is a rare fetal malformation, only six cases have been reported in English literature (1-5) and none yet from Asia. Our case is of a 26 weeks fetus born to a 20-year-old primi mother and 24-year-old father. It was a lower category Hindu couple. Mother was anemic and was undergoing treatment for anemia. On USG examination of mother showed a single line fetus of 26 weeks placental calcification, marked oligohydramnios. The fetus weighs 250 grams of unidentifiable sex on external examination. There is absence of pubis, definite buttocks and single fused lower limb ending in a bifid foot with 5 toes. X-rays show no skeletal abnormality or absence of bones. Study of internal structures will be discussed later on.

\section{KEYWORDS}

Sirenomelia, Anomalies, Agenesis, Primi, Fused, Bifid, Imperforate, Gestation, Amalia.

HOW TO CITE THIS ARTICLE: Wankhede SK, Shrivastava S. Sirenomelia: a case report. J. Evolution Med. Dent. Sci. 2016;5(14): 677-679, DOI: $10.14260 /$ jemds/2016/155

\section{INTRODUCTION}

The incidence of Sirenomelia is thought to occur 1 in 65,000 live births (Oxford Medical Database, Dysmorphology). In Sirenomelia, lower limbs are fused together. Common associated malformations include absence of external genitalia, imperforate anus, lumbosacral vertebral pelvic abnorma-lities and renal agenesis.1,2,3,4. Sirenomelia with Craniorachischisis Totalis (CT) is a rare fetal malformation. Only six cases have been reported in English literature and about three from Asia. 5,6,1,2

\section{CASE REPORT}

This case is of a 26 weeks fetus delivered in the Christian Hospital of Indore. The fetus was born to a 20 -year-old primi mother and 24-year-old father, belonging to a lower category Hindu couple.

Mother was anemic and was undergoing treatment for it. Her haemoglobin was 7.0. Gram, V.D.R.L. non-reactive, her blood group was $\mathrm{AB}+\mathrm{ve}$. At 26 weeks of gestation an Ultra sound examination was carried out which showed a single live foetus of 26 weeks with placental calcification, marked oligohydramnios.

Patient came in II stage of labor and was delivered by breech presentation, gave birth to a fresh still birth.

\section{EXTERNAL EXAMINATION}

The weight of foetus is 250 grams and is of unidentifiable sex. Absence of pubes (Fig. 5 and 6), has a definite buttock. There is a single fused lower limb ending in a bifid foot with 5 toes in each foot (Fig. 1-4). The upper limb, head, face and chest shows no abnormality. (Fig. 5-6). ${ }^{4}$

Financial or Other, Competing Interest: None.

Submission 01-01-2016, Peer Review 29-01-2016,

Acceptance 03-02-2016, Published 18-02-2016.

Corresponding Author:

Dr. S. K. Wankhede,

Block A-5, Flat No. 628, "Milan Heights,"

Bicholi Mardana, Indore-452016,

Madhya Pradesh.

E-mail: drsushilwankhede@gmail.com

DOI: 10.14260/jemds/2016/155

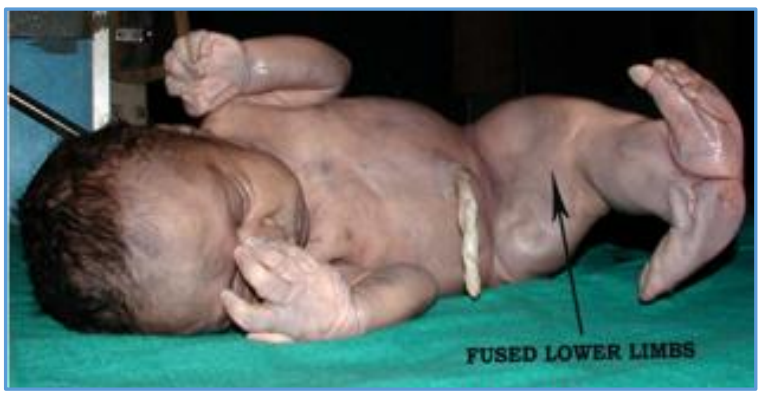

Fig. 1: External genitalia not formed. ${ }^{3}$

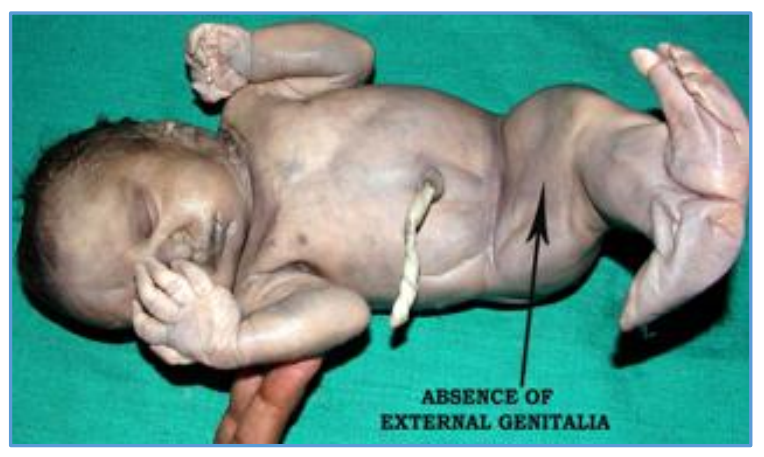

Fig. 2: Shows both Lower Limbs Fused Together, but feet are free. ${ }^{3}$

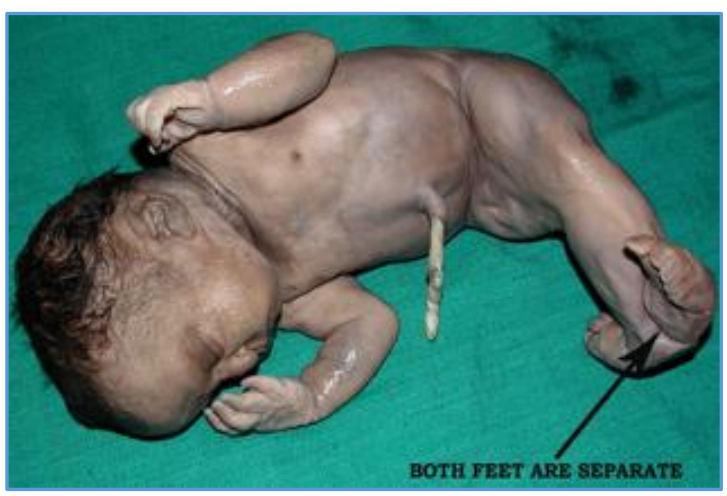

Fig. 3: Shows both Feet Apart 


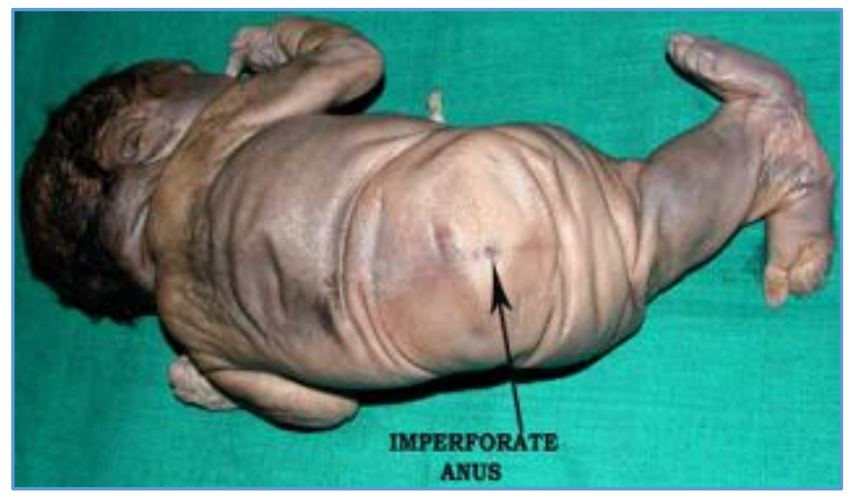

Fig. 4: Shows Imperforate Anus

\section{THE INTERNAL EXAMINATION}

It reveals total absence of urogenital system. Liver and spleen appears to be normal. Genitalia not formed. Lungs consolidated. Umbilical cord shows signs of calcification. ${ }^{1,3}$

\section{RADIOLOGICAL EXAMINATION}

The radiological examination was done by taking two radiographs in different positions, which reveals no skeletal abnormality, except the absence of pubic bone.

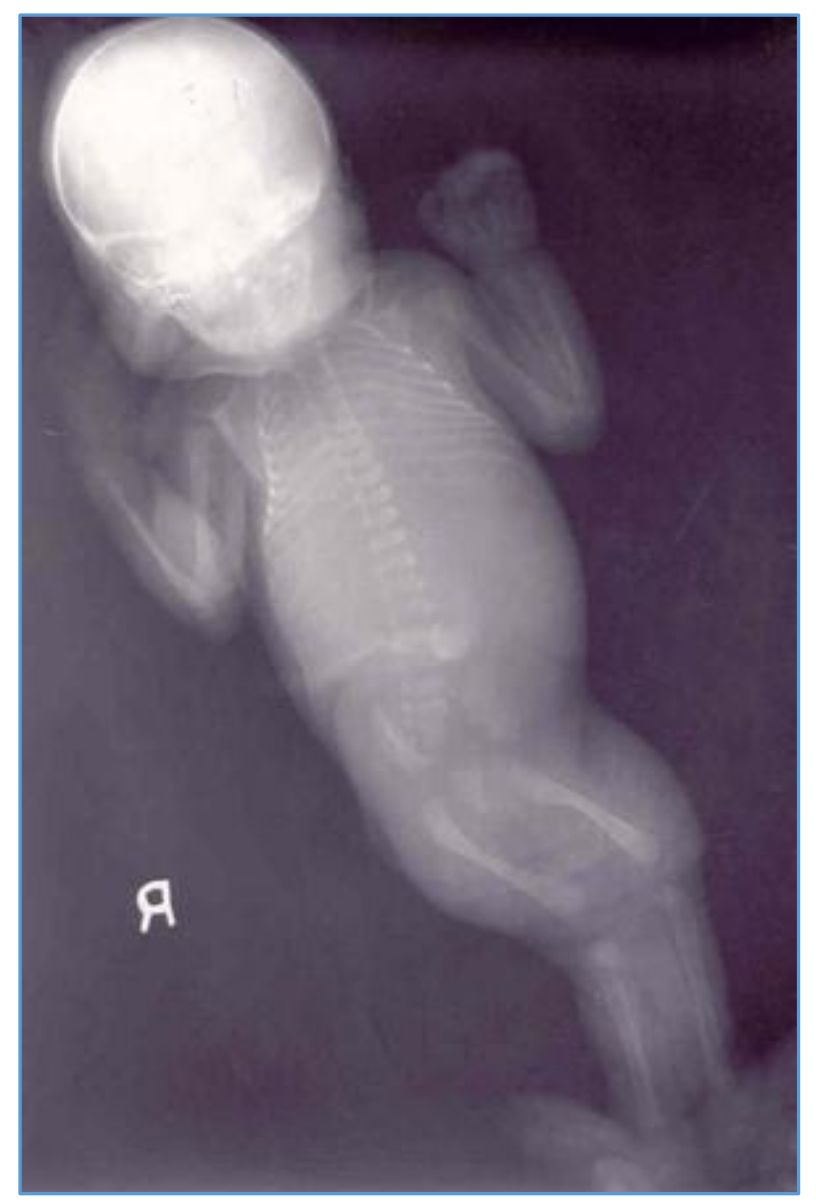

Fig. 5: Shows Absence of Pubic Bone

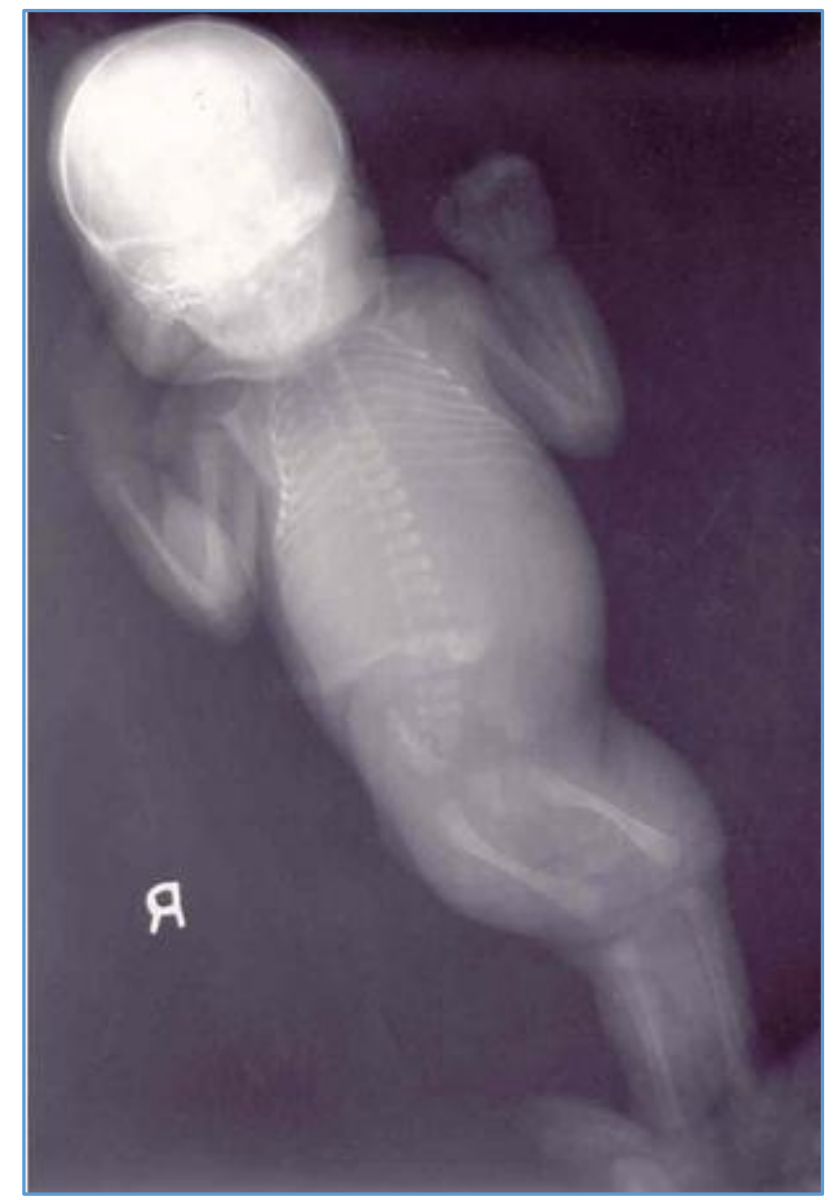

Fig. 6: Limb Bones Present

\section{DISCUSSION}

This case is somewhat similar to one reported by Ashutosh Halder of S.G.P.G.I.M.S., Lucknow. The only complication during pregnancy was anemia and oligohydramnios. Sirenomelia and craniospinal defect originate much earlier in pregnancy.

Sirenomelia is characterized by single fused lower limb includes multiple defects of contiguous organs such as Urogenital System, rectum and lower vertebrae which constitute a single developmental field. 4

This sequence is known to be associated with noncontiguous anomalies, such as CNS defect and radial dysplasia, which do not lie in the same field. $7,8,9,10$

On seeing this case, it can be attributed that during pregnancy every woman should take full precaution during pregnancy regarding drugs, diet, regular exercise, etc. so that the complications or anomalies can be avoided.

\section{CAUSES OF LIMB DEFECTS}

1. Genetic: Genetic syndromes, Autosomal disorders

2. Teratogenic: Drugs like thalidomide, dimethadione, cadmium, chemicals, viruses, radiation, hypothermia and hyperthermia.

3. Mechanical: Amniotic bands, Oligohydramnios, Uterine Defects, etc.

\section{CONCLUSION}

After the study of this case, we can reach to a conclusion that taking full precautions during pregnancy a woman can avoid 
the anomalies which are caused by various teratogenic drugs, unnecessary radiations, oligohydramnios, uterine defects, etc. Every pregnant woman should have a good nutritional diet, regular exercises and regular sleep, should be tension free. By following this she can avoid the complications.

\section{REFERENCES}

1. Marin-Padilla M. Clinical and experimental rachischisis. In: Handbook of Clinical Neurology, Vol. 32: Congenital malformations of the spine and spinal cord. Eds. Vinken PJ, Bruyn GW, Myrianthopoulos C. Amsterdam, Elsevier, 1978; pp 159-191.

2. Schinzel AA, Smith DW, Miller JR. Monozygotic twinning and structural defects. J Pediatrics 1979;95:921-930.

3. Stevenson RE, Jones KL, Phelan MC, et al. Vascular steal: the pathogenetic mechanism producing sirenomelia and associated defects of the viscera and soft tissues. Pediatrics 1986;78:451-457.
4. Young ID, O'Reilly KM, Kendall CH. Etiological heterogeneity in Sirenomelia. Pediatrics Pathol 1986; 5:31-43.

5. Battaglia S, Fraccaro M. Anencefalia in sirenide. Fol Herod Pathol 1954;3:197-204.

6. Davies J, Chazen E, Nance WE. Symmelia in one of monozygotic twins. Teratology 1971;4:367-378.

7. Pfeiffer RA, Becker V. Comments on Schwaibold's Sirenomelia and anencephaly in one of dizygotic twins. Teratology 1988;38:497-498.

8. Rodriguez JI, Palacios J, Rajquin S. Sirenomelia and anencephaly. Am J Med Genet 1991;39:25-27.

9. Rodriguez JI, Palacios J. Craniorachischisis totalis and Sirenomelia. Am J Med Genet 1992;43:732-736.

10. Perez-Aytes A, Montero L, Paya A. Single aberrant umbilical artery in a fetus with severe caudal defects. Sirenomelia or caudal dysgenesis. Am J Med Genet 1997;69:409-412. 